\title{
About the Typification of Myriophyllum aquaticum (Haloragaceae)
}

\section{Nuncia María Tur}

División Plantas Vasculares, Facultad de Ciencias Naturales y Museo, Universidad Nacional de La Plata, Paseo del Bosque s/n, 1900 La Plata, Buenos Aires, Argentina. Investigador Consejo Nacional de Investigaciones Científicas y Técnicas (CONICET). tur@museo.fcnym.unlp.edu.ar

\section{Silvia Susana Torres Robles}

División Plantas Vasculares, Facultad de Ciencias Naturales y Museo, Universidad Nacional de La Plata, Paseo del Bosque s/n, 1900 La Plata, Buenos Aires, Argentina. Becaria Consejo

Nacional de Investigaciones Científicas y Técnicas (CONICET). storresr@museo.fcnym.unlp.edu.ar

\section{Guadalupe Peter}

Centro Universitario Regional Zona Atlántica, Universidad Nacional del Comahue, Esandi y Ayacucho, 8500 Viedma, Río Negro, Argentina. Becaria Consejo Nacional de Investigaciones Científicas y Técnicas (CONICET). gpeter@criba.edu.ar

Abstract. In 1973, Verdcourt made the combination in Myriophyllum L.: M. aquaticum (Vellozo) Verdcourt based on Enydria aquatica Vellozo in the Haloragaceae. However, significant morphological differences exist between the study of the Vellozo 1825 protologue and the Vellozo 1831 plate of E. aquatica. Therefore, we propose the designation of an epitype to better fix the taxonomic application of the name $M$. aquaticum (Vellozo) Verdcourt.

Resumen. En 1973, Verdcourt realizó una nueva combinación en Myriophyllum L.: M. aquaticum (Vellozo) Verdcourt basándose en Enydria aquatica Vellozo. A través del estudio de la descripción original (1825) y lámina (1831) de E. aquatica, encontramos que los caracteres diagnósticos son diferentes. Por lo tanto en el presente trabajo se propone designar un epitipo para $M$. aquaticum (Vellozo) Verdcourt para la mejor aplicación del nombre.

Key words: Enydria, Haloragaceae, Myriophyllum.

The name Myriophyllum brasiliense Cambessèdes (Haloragaceae), described in 1830 (Cambessèdes, 1830), was applied to a species native to South America from Argentina, Brazil, Chile, Paraguay, Peru, and Uruguay (Meijden \& Caspers, 1971; Boutique \& Verdcourt, 1973; Ayres Fevereiro, 1975; Orchard, 1979, 1981; Li \& Hsieh, 1996; Negritto \& Anton, 1996; Zuloaga \& Morrone, 1999). However, this aquatic species has become almost cosmopolitan in distribution, growing as an adventitious plant in temperate and tropical regions of the world, where it was at least initially cultivated as an ornamental plant. Myriophyllum brasiliense is commonly found in freshwater bodies, where it grows in shallow quiet water, usually associated with other free-emergent floating species.

Until 1973, this aquatic plant taxon was known by the name Myriophyllum brasiliense, but as a result of Verdcourt's (1973) identification of the Vellozo (1827 [1831]) plate of Enydria aquatica Vellozo (1825 [1829]), the combined name M. aquaticum (Vellozo) Verdcourt has been applied to this species since then. Although some plant material may have been available to Vellozo, there are no surviving herbarium specimens of E. aquatica, and we have only the original description and plate for the interpretation of this name. Although the plate was not published until later in 1831, it was cited in Vellozo's protologue (1825 [1829]). The plate clearly represents original material (Art. 9.2 of the International Code of Botanical Nomenclature [McNeill et al., 2006]) and constitutes the only available element for lectotypification, and was so designated by Orchard (1979). In the Flora of Tropical East Africa, published in the same year as the new combination (Verdcourt, 1973), Boutique and Verdcourt (1973: 7) cited the type locality of $M$. aquaticum as "Brazil, junction of R. Taguahy and R. Amazon." However, the actual locality is "... fluvium Taguahy confluentium sub aquis" (Vellozo, 1825 [1829]: 57), which is near Rio de Janeiro. 




Figure 1. Photo of the epitype of Myriophyllum aquaticum (Vellozo) Verdcourt (O. C. Gões 863, RB).

We have examined and compared the plate and the original description of Enydria aquatica, and there are significant differences between the plant described (1825 [1829]) and the plant illustrated (1827 [1831]) by Vellozo, with respect to reproductive and vegeta- tive characters. The description (Vellozo, 1825 [1829]: 57) of the genus Enydria and its single species E. aquatica mentioned the solitary axillary flowers, four stamens with acuminate anthers, and the absence of evident styles, as well as tuberous roots, 
branched stems, and opposite leaves. In contrast, the species represented by the plate (1827 [1831]) designated as the lectotype has whorled axillary flowers, eight stamens with linear-lanceolate anthers, and four evident styles, with fasciculate roots, fewbranched stems, and (4)5(6) whorled leaves. Although the reported style difference could be discounted, since from his comment it is uncertain whether female flowers were actually observed by Vellozo, characters such as tuberous roots and opposite leaves are not present in $M$. aquaticum, even under extreme environmental conditions (e.g., sandy soils, desiccated ponds).

The poor incongruence of the plate and description suggest significant characters were wrongly portrayed for the plant in question, Myriophyllum aquaticum. Therefore, its lectotype is demonstrably ambiguous and cannot be critically identified for purposes of the precise application of the name. Therefore, we apply Article 9.7 of the ICBN (McNeil et al., 2006), and our selection of an epitype for Enydria aquatica serves to fix the application of this name in accordance with its current usage.

Myriophyllum aquaticum (Vellozo) Verdcourt, Kew Bull. 28: 36. 1973. Enydria aquatica Vellozo, Fl. Flumin. 57. 1825 [1829]. TYPE: Brazil. Rio de Janeiro: "Offendi rivulo quodam ad fluvium Taguahy confluentium sub aquis," Vellozo s.n. (lectotype, Fl. Flumin. Icon. 1, tab. 150, 1831. Vellozo s.n., designated by Orchard, 1979: 249). EPITYPE: Brazil. Rio de Janeiro: Petrópolis, Caelitu, Dec. 1943, O. C. Gões 863 (epitype, designated here, RB). Figure 1.

Myriophyllum brasiliense Cambessèdes, Fl. Bras. Merid. 2: 252. 1829 [1830]. TYPE: Brazil. "In paludibus prope Jondiahi haud longe ab urbe S. Pauli. Florebat Octobri," A. St. Hilaire 1082 (holotype, MPU [digital image seen]; isotype, P not seen).

Myriophyllum proserpinacoides Gillies ex Hooker \& Arnott, Bot. Misc. 3: 313. 1833. TYPE: Argentina. "Ditches at Buenos Ayres," s.d., Dr. Gillies s.n. (lectotype, designated by Orchard, 1979: 250, K [digital image seen]).

The lectotype of $M$. proserpinacoides was designated by Mora in sched. in 1970, but this was not published. Later, Orchard (1979) mentioned that the lectotype was designated by Mora. Thus, we consider this 1979 publication as the effective designation of the lectotype.

There were some materials cited by Gillies (1833) in the original description. These materials were cited as syntypes of $M$. proserpinacoides by Orchard (1979) and previously cited as paratypes by Mora in sched. in 1970.

Specimens examined. ARGENTINA. Buenos Aires: "La Plata, B. Ayres," s.d., Tweedie s.n. (syntype, Myriophyllum proserpinacoides, K [digital image seen]). CHILE. "Andes of Chili," s.d., Cuming 164 (syntype, M. proserpinacoides, K [digital image seen]).

Acknowledgments. We thank the Board of Trustees of Royal Botanic Gardens, Kew, and MPU Herbarium for the digital images of type specimens; RB for loan specimens; and Victoria C. Hollowell, John Wiersema, and an anonymous reviewer for their helpful comments.

\section{Literature Cited}

Ayres Fevereiro, P. C. 1975. Haloragáceas. Pp. 1-17 in P. R. Reitz (editor), Flora Ilustrada Catarinense. Conselho Nacional de Pesquisas-Instituto Brasileiro de Desenvolvimiento Florestal, Herbario Barbosa Rodrigues, Itajaí.

Boutique, R. \& B. Verdcourt. 1973. Haloragaceae. Pp. 1-9 in R. M. Polhill (editor), Flora of Tropical East Africa. Whiterfriars Press Ltd., London and Tonbridge.

Cambessèdes, J. 1830. XLVI. Hygrobieae Rich. Pp. 250-252 in A. F. C. P. de Saint-Hilaire (editor), Flora Brasiliae Meridionalis, Vol. 2. A. Belin, Paris.

Gillies, J. 1833. Myriophyllum proserpinacoides. P. 313 in W. J. Hooker (editor), Botanical Miscellany, Vol. 3. John Murray, London.

Li, Z. Y. \& C. F. Hsieh. 1996. New materials of the genus Myriophyllum L. (Haloragaceae) in Taiwan. Taiwania 41(4): 322-328.

McNeill, J., F. R. Barrie, H. M. Burdet, V. Demoulin, D. L. Hawksworth, K. Marhold, D. H. Nicolson, J. Prado, P. C. Silva, J. E. Skog, J. H. Wiersema \& N. J. Turland (editors). 2006. International Code of Botanical Nomenclature (Vienna Code). Regnum Veg. 146.

Meijden, R. van der. \& N. Caspers. 1971. Haloragaceae. Flora Malesiana 7: 239-263.

Negritto, M. de los A. \& A. M. Antón. 1996. Haloragaceae. Pp. 1-4 in A. Hunziker (editor), Flora Fanerogámica Argentina, Vol. 27. Programa Pro Flora (CONICET), Córdoba.

Orchard, A. E. 1979. Myriophyllum (Haloragaceae) in Australasia: 1. New Zealand: A revision of the genus and a synopsis of the family. Brunonia 2(2): 247-287.

. 1981. A revision of South American Myriophyllum (Haloragaceae), and its repercussions on some Australian and North American species. Brunonia 4(1): 27-65.

Vellozo, J. M. da C. 1825 [1829]. Enydria. Pp. 56-57 in J. M. da C. Vellozo (editor), Florae Fluminensis, Vol. 1. Typographia Nationali, Rio de Janeiro.

_. 1827 [1831]. Enydria aquatica, tab. P. 150 in J. M. da C. Vellozo (editor), Florae Fluminensis Icones. Senefelder, Paris.

Verdcourt, B. 1973. A new combination in Myriophyllum (Haloragaceae). Kew Bull. 28(1): 36.

Zuloaga, F. O. \& O. Morrone. 1999. Catálogo de las Plantas Vasculares de la República Argentina II. AcanthaceaeEuphorbiaceae (Dicotyledoneae). Monogr. Syst. Bot. Missouri Bot. Gard. 74. 